\title{
Mountaintop mining plans close to defeat
}

\section{Environmental review details 'unacceptable' impacts.}

\section{BY NATASHA GILBERT}

$\mathrm{T}$ The rising tide of scientific evidence and public protest - against mountaintop mining looks set to claim its first major victory. By the end of this year, the US Environmental Protection Agency (EPA) is expected to revoke a permit allowing mining company Arch Coal to extract coal from the Appalachian Mountains in West Virginia. This would be the first time a permit for the controversial mining practice, long suspected of causing environmental damage, has been vetoed by the agency.

A scientific review (see go.nature.com/ hsuhrt) carried out by the EPA and published on 15 October concluded that the project, Spruce 1, would have "unacceptable" effects on water quality and wildlife, and recommended its permit be revoked. Carol Raulston,

a spokeswoman for the National Mining Association (NMA), based in Washington DC, told Nature: "The NMA has no reason to believe the EPA will not follow the recommendations in its final determination on the Spruce permit."

The move is likely to set the tone for decisions on other mining projects. More than 100 surface-mining permits are pending approval with the Army Corps of Engineers, which is responsible for investigating, developing and maintaining the nation's water and related environmental resources. The corps issued approval for the Spruce 1 project in 2007 to Mingo Logan, a subsidiary of Arch Coal. But

DNATURE.COM

For more on mountaintop mining see: go.nature.com/9qlirbu the EPA can revoke a permit if it feels that environmental concerns have not been fully addressed.

"If the EPA proceeds with its unlawful veto of the Spruce permit, as it appears determined to do, every business in the nation would be put on notice that any lawfully issued permit can be revoked at any time according to the whims of the federal government," says Kim Link, a spokeswoman for Arch Coal.

Mountaintop mining exposes seams of coal near mountain peaks by stripping away forests and breaking up rock with explosives. The debris is often dumped in the valleys below. The EPA review says that Spruce 1 would increase the electrical conductivity of stream water (a measure of its ionic concentration) to unacceptably high levels, harming aquatic wildlife.

The NMA says that the EPA's use of electrical conductivity as a proxy for water pollution is "faulty science". "Conductivity is but one metric of water quality and is not recognized by hydrologists as satisfactory when used as the chief or only metric," says Luke Popovich, a spokesman for the NMA. However, research has shown a strong correlation between increased levels of conductivity and harm to aquatic macro-invertebrates (see Nature 466, 806; 2010).

Arch Coal had already filed a lawsuit in April challenging the EPA's authority to veto permits. The company now plans to submit a rebuttal to the review by 5 November. 